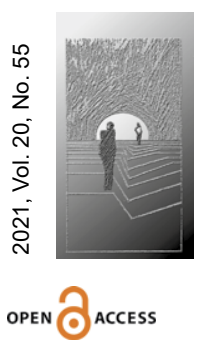

\title{
Internetowa porada psychologiczna - perspektywa językoznawcza
}

\section{STRESZCZENIE}

CEL NAUKOWY: Celem artykułu jest analiza porad psychologicznych umieszczonych na portalu edukacyjnym Librus Rodzina z perspektywy językoznawczej.

PROBLEM I METODY BADAWCZE: Problemem badawczym jest określenie zakresu tematycznego internetowych porad psychologicznych, analiza ich struktury formalnej, zastosowanych strategii nadawczo-odbiorczych oraz mechanizmów językowych, ze szczególnym uwzględnieniem zjawisk leksykalnych i składniowych. Wykorzystano metody badań stylistycznych, krytycznej analizy dyskursu oraz genologii lingwistycznej.

PROCES WYWODU: W artykule wskazano wzrastającą rolę mediów elektronicznych w procesie wychowania, przedstawiono przyczyny i skutki tego zjawiska. W części analitycznej skoncentrowano się na omówieniu wewnętrznej architektury tekstów porad internetowych ze wskazaniem charakterystycznych dla nich mechanizmów językowych.

WYNIKI ANALIZY NAUKOWEJ: W wyniku analiz stwierdzono, że zakres tematyczny internetowych porad psychologicznych dotyczy istotnych problemów nurtujących rodziców (depresje, fobie szkolne, zaburzenia mowy, emocje dziecka). Na wewnętrzną strukturę porady internetowej składa się siedem elementów składowych, a językowe ukształtowanie wypowiedzi jest typowe dla stylu popularnonaukowego, co znacząco ułatwia percepcję specjalistycznych treści przez rodziców.

WNIOSKI, INNOWACJE, REKOMENDACJE: Profesjonalne porady psychologiczne umieszczane na ogólnodostępnym portalu edukacyjnym są ważnym wsparciem dla rodziców i mogą służyć doskonaleniu ich kompetencji rodzicielskich. Stanowią też uzupełnienie dotychczasowej pomocy, jaką oferują tradycyjne placówki oświatowe.

\section{$\rightarrow$ SŁOWA KLUCZOWE: PORADA PSYCHOLOGICZNA, RODZINA, INTERNET,} KOMUNIKACJA JĘZYKOWA, STYLISTYKA JĘZYKOZNAWCZA 


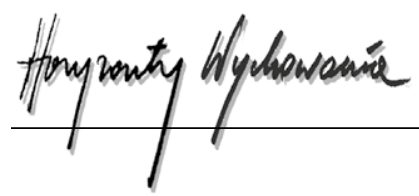

ABSTRACT

Internet Psychological Counseling - a Linguistic Perspective

RESEARCH OBJECTIVE: The aim of this paper is to analyze the psychological counseling posted on the educational portal Librus Family from a linguistic perspective.

THE RESEARCH PROBLEM AND METHODS: The research problem is to define the thematic scope of online psychological counselling: analyze its formal structure, the applied transmission-reception strategies and linguistic mechanisms, with particular emphasis put on lexical and syntactic phenomena. The methods used for research included stylistic research, critical discourse analysis and linguistic genology.

THE PROCESS OF ARGUMENTATION: The article indicates the increasing role of electronic media in the process of upbringing, presents the causes and consequences of this phenomenon. The analytical part focuses on the discussion of the internal architecture of Internet counselling texts with the indication of the linguistic mechanisms characteristic for them.

RESEARCH RESULTS: As a result of the analyses, it was found that the thematic scope of online psychological counseling relates to important problems troubling parents (depression, school phobias, speech disorders, child emotions). The internal structure of the online advice consists of seven components, the linguistic formulation of statements is typical for the popular science style, which significantly facilitates the perception of specialized content by parents.

CONCLUSIONS, INNOVATIONS, AND RECOMMENDATIONS: Professional psychological counselling on a public educational portal is an important support for parents and can improve their parenting skills. It also completes the existing support offered by traditional educational institutions.

\section{$\rightarrow$ KEYWORDS: PSYCHOLOGICAL COUNSELING, FAMILY, INTERNET, LANGUAGE COMMUNICATION, LINGUISTIC STYLISTICS}

\section{Wprowadzenie}

Czynniki zewnętrzne, takie jak zwiększone tempo życia, sytuacja ekonomiczna rodzin, aktywność zawodowa rodziców (przede wszystkim zwiększenie wymiaru czasu pracy), rozwój technologii znacząco wpływają na funkcjonowanie polskich rodzin, w tym na sposób wychowania dzieci i obowiązujący system wartości. Badacze podejmujący kwestie kondycji polskich rodzin wyraźnie wskazują na postępujące zjawisko kryzysu polskiej rodziny (por. Rawicka, 2020; Tomasik, 1998). Zmiany cywilizacyjne prowadzą do dewaluacji tradycyjnych wzorów, zachowań, więzi, powodując poczucie samotności, lęk i chaos (Nowak-Dziemianowicz, 2013, s. 36). Dlatego wielu rodziców, świadomych swojej odpowiedzialności za wychowanie dzieci i kształtowanie ich życiowych postaw (Dakowicz i in., 2015, s. 180), szuka wsparcia u nauczycieli, wychowawców, psychologów. 
W ostatnich latach poza instytucjami, takimi jak szkoła, poradnie psychologiczno-pedagogiczne istotną rolę we wspomaganiu rodziny w podnoszeniu kompetencji wychowawczych, rozumianych tu jako swoista sprawność czy umiejętność wyrażająca się w interakcji i komunikacji z dzieckiem (Jackiewicz i Białecka-Pikul, 2019, s. 20), pełnią również portale internetowe, głównie te zintegrowane z systemem edukacyjnym, jak np. Librus.pl. Szczególnie w czasie pandemii, kiedy bezpośrednie kontakty zostały znacząco ograniczone, niemal cały dyskurs edukacyjny realizowany jest przez medium internetowe, a nowoczesne techniki wspierają pracę nauczycieli (por. Makarewicz, 2017, s. 68) i umożliwiają komunikację między rodzicami a szkołą. Dzięki portalom edukacyjnym możliwe jest nie tylko przekazywanie informacji o sprawach bieżących, wynikach w nauce, organizowanych wydarzeniach, metodach pracy z uczniem, stały się one dla rodziców również źródłem wiedzy. Szeroko pojęte poradnictwo związane z wychowaniem dzieci jest jednym z dynamicznie rozwijających się obszarów w edukacyjnej przestrzeni internetowej. Wydaje się, że ta sfera dyskursu edukacyjnego staje się coraz bardziej istotna, zwłaszcza w sytuacjach kryzysowych, do których niewątpliwie zaliczyć można czas pandemii COVID-19. Konieczność znacznego ograniczenia dotychczasowych aktywności społecznych, osamotnienie, brak interakcji z grupą rówieśniczą jest przyczyną zaburzeń emocjonalnych, depresji, obniżenia nastroju, kłopotów z organizacją czasu (por. Heitzman, 2020, s. 198; Pikuła, Jagielska i in., 2020; Pikuła, Grewiński i in., 2020). Rodzice i opiekunowie niewyposażeni w wiedzę psychologiczną czy pedagogiczną, często pozbawieni bezpośredniego niegdyś wsparcia przedstawicieli starszego pokolenia, szukają pomocy nie tylko u specjalistów, ale także w internetowych poradnikach poświęconych kwestiom opieki i wychowania. Wybór tej formy wydaje się naturalny, bowiem większość rodziców należy do generacji, na którą wpływ miał rozwój mediów cyfrowych. Internet jest zatem platformą wymiany myśli i wiedzy służących rodzinie, wspomagających ją ${ }^{1}$, a jego rola wzrosła szczególnie w czasie obecnego kryzysu spowodowanego pandemią COVID-19.

\section{Cel i metoda badań, charakterystyka źródła}

Celem tego artykułu jest analiza porad psychologicznych zamieszczonych na portalu edukacyjnym Librus Rodzina z perspektywy językoznawczej. Przedmiotem rozważań będzie określenie zakresu tematycznego porad, omówienie ich struktury formalnej, zastosowanych strategii nadawczo-odbiorczych oraz analiza zjawisk językowo-stylistycznych, w tym stosowanych struktur składniowych i leksykalnych. W wyniku tego możliwe stanie się zrekonstruowanie obrazu współczesnej rodziny, jaki wyłania się z porad

${ }^{1}$ Pomijam w niniejszych rozważaniach szczegółowy opis roli mediów, w tym również ich negatywnych skutków. Zagadnieniu temu poświęcony został m.in. tom Rodzina w mediach - Horyzonty Wychowania, 19(49) z 2020 r. 


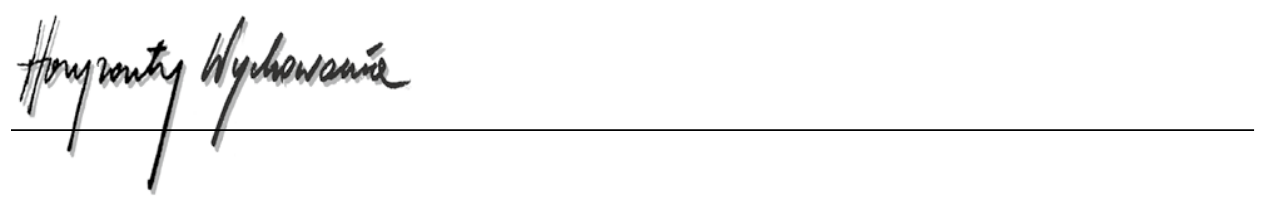

psychologicznych. W warstwie językowej ujawniają się bowiem nie tylko intencje nadawców, ale i kreowany przez nich obraz świata (por. Makarewicz, 2017, s. 67).

Do analiz wybrano dwadzieścia sześć adresowanych do rodziców porad umieszczonych na stronie internetowej Librus Rodzina w okresie od maja 2019 do lutego 2021 roku. To część największego portalu edukacyjnego Librus.pl, za pomocą którego 7700 szkół w Polsce dokumentuje przebieg procesu nauczania. Korzysta z niego 310000 nauczycieli oraz 4300000 rodziców i uczniów (librus.pl). Jak pisze Renata Makarewicz w książce poświęconej dyskursowi szkolnemu: „Początkowo e-dziennik był tylko wsparciem w obsłudze administracyjnej szkoły, z czasem przekształcił się w miejsce gromadzące informacje o uczniu i jako narzędzie komunikacji między pracownikami szkoły a rodzicami ucznia" (Makarewicz, 2017, s. 67). Warto w tym miejscu podkreślić, że obecnie obserwujemy sukcesywne rozszerzanie się zakresu jego funkcjonowania i dostosowywanie go do potrzeb odbiorców. Jednym z dowodów jest uruchomienie platformy Librus Rodzina. Publikowane są tu różnorodne materiały skoncentrowane wokół zagadnień związanych z opieką i wychowaniem, w tym porady psychologiczne adresowane do rodziców. Ich autorami są doświadczeni psychologowie, terapeuci rodzinni, teologowie, pedagodzy o bogatym dorobku zawodowym.

Wszystkie porady będące przedmiotem zainteresowania w niniejszym opracowaniu zostały umieszczone w kategorii psychologia. Duży zasięg platformy oraz wieloaspektowe działania, których celem jest wsparcie zarówno dyrektorów szkół, nauczycieli, uczniów, jak i rodziców pozwalają na postawienie tezy, że polscy uczestnicy systemu edukacyjnego mają stały, systematyczny kontakt z treściami publikowanymi na tym portalu.

\section{Analiza materiału}

Wraz z globalnymi przemianami społecznymi porada oraz poradniki zyskują we współczesnym świecie coraz większe grono zainteresowanych. Jedną z grup odbiorców stanowią rodzice, którzy szukają rozwiązania problemów związanych z rozwojem i wychowaniem dzieci w poradnikach, także internetowych. To zwiększone zapotrzebowanie znajduje odzwierciedlenie w coraz bogatszej ofercie porad, których autorami są zarówno specjaliści, tematyczne portale internetowe, jak i niekiedy rodzice, chcący podzielić się swoimi doświadczeniami (np. blogi parentingowe).

Rada, porada oraz poradnik jako gatunki stały się przedmiotem opracowań językoznawczych. Na szczególną uwagę zasługują prace Ewy Ficek, która w książce Poradnik. Model gatunkowy i jego tekstowe wizualizacje (2013a) ${ }^{2}$ dokonała szczegółowej charakterystyki gatunku z uwzględnieniem jego komponentów pragmatycznych, strukturalnych, poznawczych, stylistycznych i aksjologicznych.

${ }^{2} \mathrm{~W}$ pracy zawarta jest bogata bibliografia dotycząca omawianego tematu. 
Wypracowany przez autorkę model będzie podstawą niniejszych analiz. Zebrany w niniejszym artykule materiał egzemplifikacyjny pozwoli bowiem na wskazanie wyznaczników gatunkowych jednej z odmian porady, czyli porady psychologicznej.

\section{Zakres tematyczny porad psychologicznych}

Badane porady koncentrują się wokół trzech głównych kręgów tematycznych. Są to:

a) rozwój dziecka ( $m$.in. koncentracja, regulacja emocji, negatywne emocje, typy osobowości, rola integracji sensorycznej);

b) zaburzenia emocjonalne (depresja, fobie, trudności w uczeniu się, zaburzenia w odżywianiu się, zaburzenia mowy);

c) sytuacje kryzysowe (m.in. sytuacja dziecka a rozwód rodziców, śmierć, starta bliskich, relacje, sytuacja dzieci oraz seniorów w pandemii).

Już wstępny ogląd poruszanej tematyki porad pozwala przyjąć, że ich autorzy starają się podejmować kwestie powszechne, których rozwiązania poszukuje wielu rodziców. Warto podkreślić, że jedną z cech internetowej porady psychologicznej jest jej aktualizacyjny charakter. Analizowane tu publikacje nawiązują bowiem do bieżących sytuacji, w poradach zostały uwzględnione m.in. trudności, jakie wiążą się z obecną pandemią. Takie odniesienia uaktualniają przekaz, dostarczają rodzicom niezbędnej wiedzy i przydatnych wskazówek na temat tego, jak postępować w sytuacjach kryzysowych.

\section{Struktura porady psychologicznej}

Na początku tej części rozważań należy wskazać na istotną różnicę między dwoma pokrewnymi gatunkami, tj. „radą” a „poradą”. Zgodnie z ustaleniami Ewy Ficek porada ma zwykle charakter profesjonalny i wynika ze specjalistycznej wiedzy radzącego (Ficek, 2013b, s. 1s. 146) ${ }^{3}$, co wpływa na wewnętrzną strukturę porady. W każdym tekście będącym realizacją określonego gatunku możemy bowiem wyodrębnić „wyspecjalizowane segmenty o charakterze strategicznym, pozwalające odbierać go jako wewnętrznie zorganizowaną całość. Spełniają one funkcję nośników treści kontekstualizujących i antycypujących przebieg dyskursu. Oznacza to, iż przyciągają uwagę odbiorcy, ułatwiają interpretację tekstu oraz orientację w jego strukturze linearnej i informacyjnej" (Ficek, 2013a, s. 114). Wewnętrzna architektonika tekstu służyć ma zatem przekazaniu prezentowanych treści, ułatwić odbiorcy odczytanie oraz poruszanie się w jego obrębie. Z przeprowadzonych analiz wynika, że porady psychologiczne umieszczone na portalu Librus Rodzina realizują następujący schemat kompozycyjny:

${ }^{3}$ Opracowanie to zawiera szczegółowe rozważania na ten temat, autorka prezentuje stanowiska językoznawców oraz poradoznawców. 


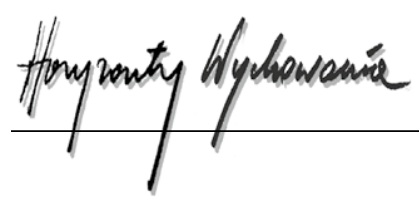

- tytuł;

- część inicjalna, będąca wprowadzeniem do omawianego zagadnienia;

- prezentacja poruszanego zagadnienia z perspektywy naukowej, wraz z podaniem wyników badań oraz wypływających z nich wniosków;

- właściwa porada;

- bibliografia;

- nota o autorze;

- elementy ikonograficzne.

Przyjrzyjmy się zatem poszczególnym członom kompozycyjnym.

Z analizy wynika, że tytuły porad psychologicznych pełnią zarówno funkcje nominalną, deskryptywną i pragmatyczną (Gajda, 1987, s. 83). Mają za zadanie przyciągnąć uwagę odbiorcy, zaintrygować, skłonić do lektury (Wójcicka, 2006, s. 115). Jak pisał Stanisław Gajda: „Tytuł nazywa tekst, ale stanowi także ramową metatekstową wypowiedź, tj. o tekście w tekście, stąd treść tytułu pozostaje prawie zawsze w związku z treścią tekstu" (Gajda, 1987, s. 83). Realizacja tych funkcji możliwa jest dzięki składniowemu ukształtowaniu, który w przypadku omawianych porad realizują następujące schematy ${ }^{4}$ :

- grupa nominalna + pytanie (Gniew, złość, emocje - jak wspierać dziecko?; Wysoko wrażliwe dziecko - kim jest?; Fobie u dziecka - jak sobie z nimi radzić?; Koncentracja uwagi u dziecka - jak działa?; Zaburzenia odżywiania - czy dotyczy to mojego dziecka?; Depresja u dzieci i młodzieży - co powinno nas niepokoić?);

- pytanie (Jak myśleć pozytywnie i uwierzyć w siebie?; Jak znaleźć pozytywy w trudnej sytuacji?; Jak rozmawiać o epidemii z dzieckiem (i nie tylko)?; Dlaczego pozwolić dziecku na to, by płakało?; Jak rozmawiać z dzieckiem o stracie?);

- pytanie + równoważnik zdania (Kim jest twoje dziecko? Introwertyk a ekstrawertyk; Za co jesteś wdzięczny? O sposobie na szczęście; A dlaczego nie 6? Wysokie oczekiwania kontra wyniki w nauce).

Tytuł stanowi więc etykietę, informuje o zawartości dalszej części tekstu, pełni też funkcję magnesu, który ma zachęcić potencjalnych odbiorców do zapoznania się z całym tekstem (por. Żydek-Bednarczuk, 2005, s. 171-172; Ślawska, 2008, s. 118; Wójcicka, 2006, s. 114-115). Natomiast analiza warstwy leksykalnej tytułów porad psychologicznych pokazuje, że ich autorzy stosują kilka strategii, by zwrócić uwagę odbiorców rodziców. Jedną z nich jest posługiwanie się terminami funkcjonującymi w specjalistycznym dyskursie psychologicznym, nazywającymi procesy psychiczne bądź zaburzenia (np. fobia, depresja, integracja sensoryczna, regulacja emocji) (por. Seniów, 2017). Można założyć, że obecność terminów znanych rodzicom dość pobieżnie, niemal ze słyszenia, oraz zapowiedź ich wyjaśnienia jest skutecznym zabiegiem przyciągającym uwagę odbiorców.

Część inicjalna omawianych porad obejmuje zwykle zaledwie akapit, w którym autorzy definiują tytułowe pojęcia, powołując się przy tym na wyniki badań naukowych. Oto jeden z reprezentatywnych przykładów:

\footnotetext{
${ }^{4}$ Podobne ustalenia wynikają z pracy E. Ficek poświęconej poradnikom (2013a, s. 115).
} 
Wysoko wrażliwe dzieci są w naszej populacji od zawsze. Wcześniej mówiono o nich, że są nieśmiałe, że to introwertycy, dzieci bojaźliwe lub tzw. „wolno rozgrzewające się”. Dzięki licznym badaniom wykonanym przez zespół naukowców pod skrzydłami Elaine Aron (również osoby wysoko wrażliwej) wiemy, że to nie do końca prawda. Wśród wysoko wrażliwych osób $70 \%$ to introwertycy, ale pozostałe $30 \%$ to ekstrawertycy. Kim więc jest dziecko wysoko wrażliwe? (Jasińska, 2021).

Nasycenie tekstu specjalistycznym słownictwem, danymi liczbowymi, nazwiskami badaczy oraz obiektywizm nadawcy nieujawniającego swoich sądów cechuje część inicjalną, wieńczy ją zaś pytanie retoryczne, którego celem jest nawiązanie relacji z odbiorcą, zachęcenie go do dalszej lektury.

Trzeci segment porady jest bardziej rozbudowany, tu definiowane są tytułowe zjawiska psychologiczne, ich szczegółowa charakterystyka czy typowe objawy zaburzeń. W analizowanych poradach dominuje styl popularnonaukowy, autorzy stosują następujące strategie: ograniczenie liczby terminów, wyjaśnianie treści niezbędnych do przekazania informacji, wewnętrze uporządkowanie wypowiedzi, odwoływanie się do doświadczeń życiowych, wprowadzenie elementów języka potocznego (Florczewska, 2002, s. 186) ${ }^{5}$. Przyjrzyjmy się zatem, jak te strategie realizują się w analizowanych tu poradach psychologicznych. Celem tej części porady jest zapoznanie czytelnika z opisywanym zagadnieniem i dostarczenie mu specjalistycznej wiedzy. Zakres podawanych informacji ma charakter funkcjonalny, autor podaje tyle treści, ile uznaje za niezbędne do zrozumienia porady przez odbiorcę. Ta część porady pełni też ważną funkcję z perspektywy relacji nadawczo-odbiorczych. Autor buduje swój wizerunek, pokazuje się jako ekspert, kompetentny specjalista zorientowany w najnowszych badaniach, co daje mu prawo do udzielania rad. Czytelności prezentowanych treści służy między innymi strategia wyliczania, stosowana np. w charakterystyce objawów bądź w definiowaniu omawianych pojęć, np.:

Cechy świadczące o głębokim przetwarzaniu:

- powolne i stopniowe przyzwyczajanie się do nowych sytuacji i rzeczy z uwagi na silną potrzebę obejrzenia, obserwowania i podjęcia decyzji, czy włączyć się do działania, czy też nie;

- trudności z podejmowaniem decyzji wynikające z potrzeby zebrania wielu szczegółów i rozważenia za i przeciw;

- raczej wolne przyswajanie nowych osób, rzeczy czy sytuacji np. w szkole;

- zadawanie głębokich, refleksyjnych pytań, często ponad wiek dziecka;

- używanie trudnych słów, którymi zwykle posługują się dużo starsze dzieci, a nawet dorośli (Jasińska, 2021).

${ }^{5}$ Podobne właściwości stylu popularnonaukowego wymienia Anna Starzec, wskazując, że cechuje go: ekspresywność i subiektywność, obrazowość i konkretność, wyrazistość, dynamizm, symulatywność, dialogowość i informacyjna sekundarność (za: Bortliczek, 2017, s. 12). 


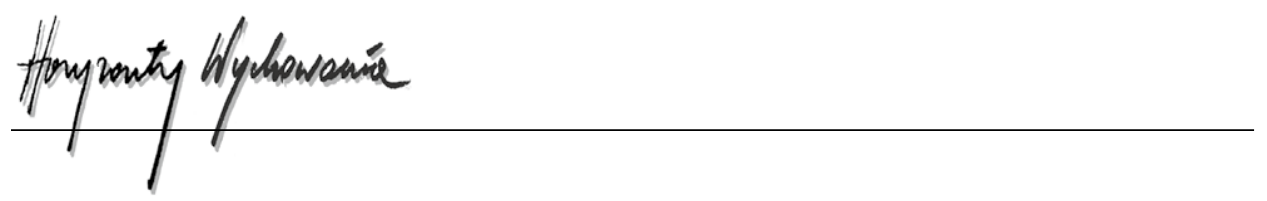

Wśród zjawisk leksykalnych na uwagę zasługuje obecność specjalistycznych terminów zarówno jedno-, jak i wieloelementowych (np.: „wysoka wrażliwość”; „bodziec”; „kora mózgowa”; „kortyzol”; „fobia”; „dobrostan psychiczny” itp.). Są one zawsze wyjaśniane, a jedną z najczęstszych technik jest użycie zdań rozwijających z komponentem „czyli” (np.: „ambiwertycy, czyli ci, którzy są swego rodzaju mieszanką obu typów”; „Cały proces koregulacji, czyli współregulacji, zaczyna się od budowania relacji”; „poziom kortyzolu (hormonu stresu) jest na przeciętnym poziomie. Czyli jest go w sam raz - ani za mało, ani za dużo"). Wszystkie zabiegi służą autokreacji nadawcy, który, by zyskać zaufanie odbiorcy i prawo do udzielania rad, pokazuje się w roli eksperta, swobodnie poruszającego się po omawianej tematyce. Zgodnie z wyróżnikami stylu popularnonaukowego widać jednak wyraźne zmniejszenie dystansu między nadawcą (ekspertem) i odbiorcą (niefachowcem) w celu uniknięcia dysonansu poznawczego (Bortliczek, 2017, s. 12). Autorzy porad stosują strategię utożsamiania się z odbiorcą, czego językowym wykładnikiem jest używanie czasowników w 1. os. I.mn. (np.: „ograniczymy sobie możliwość zobaczenia siebie w innym świetle”) oraz zaimków „my”, „nasz” (np.: „Oczywiście żadne z naszych dzieci, podobnie jak i my sami, nie jest w $100 \%$ introwertyczne czy ekstrawertyczne”; „Nasz mózg jest pełen utartych szlaków myślenia, dzięki którym szybciej łączy różne doświadczenia, wiedzę, myśli”). Zabieg ten pozwala na zmniejszenie dystansu między odbiorcą a nadawcą, który występuje nie tylko w roli eksperta, ale też zbliża się do czytelnika, jest jednym z rodziców, mówi w ich imieniu. Takie konstruowanie instancji nadawczo-odbiorczych buduje swego rodzaju dychotomiczny obraz świata, podzielonego na dwie osobne przestrzenie: dorosłych i dzieci. Z analizowanych porad wyraźnie wynika, że nadawca ekspert stara się być swoistym przewodnikiem odbiorcy rodzica po świecie dziecka. $Z$ racji swojego przygotowania merytorycznego, a także doświadczenia życiowego wie więcej niż rodzic, dlatego dzieli się z nim swoim doświadczeniem i służy radą.

Kolejny element strukturalny omawianego gatunku to właściwa porada, czyli segment, w którym nadawca doradca udziela konkretnych wskazówek i rad, pozwalających na rozwiązanie problemu bądź wdrożenie pożądanego działania. Celem jest tu wywarcie wpływu na zachowanie odbiorcy, skłonienie go do podjęcia określonych działań, czemu służy składniowe ukształtowanie wypowiedzi. Są to przede wszystkim konstrukcje z czasownikiem w formie drugiej osoby trybu rozkazującego, często mające charakter bezpośrednich wskazówek postępowania (np.: „Zadbaj o to, aby szczególnie młodsze dzieci były najedzone, nawodnione i wypoczęte”; „Nie używaj sam i nie pozwól, by inni używali w stosunku do dziecka negatywnych, obrażających je etykiet”; „Doceniaj starania dziecka, nawet jeśli nie zakończą się one sukcesem”; „Zmień myślenie od dziś”; „Na to zwróć uwagę!"). Natomiast forma pierwszej osoby liczby mnogiej trybu rozkazującego używana jest, by podkreślić identyfikowanie się nadawcy z odbiorcą (np.: „Bądźmy czujni! Korzystajmy z pomocy telefonów zaufania!"). Autorzy posługują się też zdaniami, które są swoistą symulacją potencjalnie możliwych zdań, dostarczając rodzicom gotowych formuł językowych, za pomocą których mogliby oni komunikować się z dzieckiem, a tym samym wprowadzić w życie zalecane porady (np.: „jesteś bardzo zdolna, na pewno 
sobie poradzisz"). W tej części autorzy porad przywołują również tzw. przykłady z życia, które osadzają poradę w kontekście realnych bądź potencjalnie możliwych sytuacji (np.: „Dziecko, które dotychczas po powrocie ze szkoły, w oczekiwaniu na rodziców, spędzało czas pod okiem babci, teraz zostaje z inną osobą”; „Jeżeli dziecko będzie mogło w kuchni razem z mamą korzystać z przepisów zmarłej babci, a zimą zastąpić wujka w dokarmianiu ptaków...”) bądź odtwarzają proces myślowy dziecka (np.: „co o mnie powiedzą, pomyślą, jak się odezwę, to na pewno powiem coś głupiego, niezwiązanego z tematem i się skompromituję, na pewno wszyscy widzą, jak się denerwuję, jak trzęsą mi się ręce i jak pot zalewa mi czoło"). Wprowadzenie takich elementów wpływa na czytelność wypowiedzi, neutralizuje naukowy, intelektualny styl, który mógłby stanowić istotną barierę w odbiorze prezentowanych treści. Czyni przekaz mniej abstrakcyjnym, pozwala rodzicowi unaocznić, jak zastosować poradę w życiu. Złagodzenie specjalistycznej narracji odbywa się również poprzez wprowadzenie do tekstu elementów języka potocznego. Są to zarówno pojedyncze leksemy (,supermoc”; „gadanie”; „maminsynek”), potoczne wyrażenia i zwroty (np.: „czarna robota”; „karczemna awantura”; „niezaopiekowana złość”), jak i obrazowe porównania (np.: „dzieci krzyczą, biją, plują, gryzą, kopią, zaciskają zęby, pięści itp., czyli zachowują się jak zwierzęta w klatce”; „Sięganie po pomoc, przy doświadczaniu obniżonego nastroju powinno być, szczególnie teraz, tak powszechne, jak sięganie po pomoc, gdy boli nas głowa, gardło czy mamy katar”). Porady kończą się przywołaniem anegdot z życia, stylizowanych często na język komunikacji codziennej (Handke, 2008, s. 272-306).

Potwierdzeniem wiarygodności autora porad oraz prawdziwości formułowanych przezeń sądów jest umieszczona na końcu bibliografia, która zwykle obejmuje od trzech do pięciu pozycji. W tekście głównym nie odnajdziemy przypisów czy odnośników do wykorzystywanych tekstów, ale przywołanie tytułów publikacji naukowych na końcu wywodu jest dla odbiorcy informacją o możliwości zgłębienia tematu poprzez sięgnięcie do polecanych lektur. Ostatnim werbalnym elementem porady internetowej jest krótki opis sylwetki autora, a ściślej autorki, ponieważ w przypadku materiałów analizowanych w niniejszym opracowaniu wszystkich porad udzielały kobiety. Podane są informacje o ich wyksztalceniu, doświadczeniu zawodowym oraz życiowym.

Integralną częścią porady są elementy ikonograficzne, obok językowych środków wyrazu mają one istotne znaczenie dla odbioru całego tekstu (por. Loewe, 2007, s. 126), odwołują się do naturalnej dla człowieka zdolności do myślenia obrazami (Szylko-Kwas, 2017, s. 138). Zdjęcia uzupełniają tekst, wizualizują opisywany za pomocą kodu werbalnego element rzeczywistości. Słowo i obraz wchodzą zatem w intermodalne relacje, które współtworzą sens przekazu (por. Maćkiewicz, 2017, s. 41). Połączenie kodu werbalnego i wizualnego przyciąga uwagę odbiorcy, ale i wywołuje u niego pożądane emocje (np. czułość, zainteresowanie, radość, ciekawość).

Analiza porad psychologicznych pozwala na rekonstrukcję wpisanego implicite w teksty porad systemu wartości. Język bowiem, a szczególnie jego warstwa leksykalna jest nośnikiem informacji o bliskich nadawcy komunikatu wartościach (Puzynina, 1992, s. 118). W niniejszym artykule przyjmuję stanowisko Jadwigi Puzyniny, która 


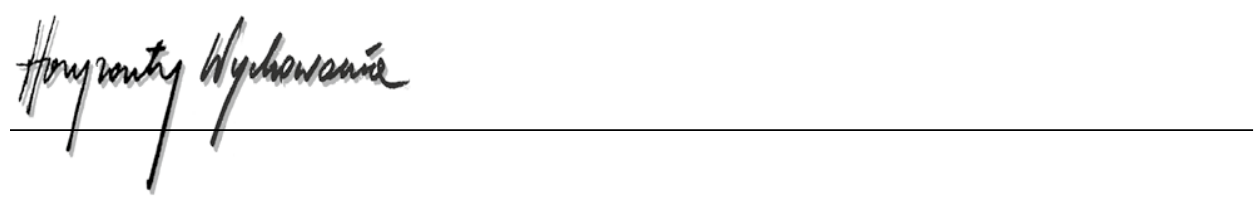

wartościowanie definiuje jako „sposób i zakres wyrażania wartości przez jednostki systemu językowego" (Puzynina, 1991, s. 129) Z przeprowadzonych analiz wyłania się obraz rodziny jako wspólnoty, ważnej przestrzeni do rozwoju emocjonalnego dziecka. Językowymi wykładnikami takich wartości, jak bliskość, zaufanie, poczucie bezpieczeństwa są leksemy:

- wspólnota, wspólny, wspólnie (np.: „Wspólnie z dziećmi możemy czytać, spacerować (...)”; „Można wspólnie z dzieckiem ćwiczyć rozwiązywanie problemów”);

- razem („Czasami pomaga po prostu bycie razem z dzieckiem”; „Czas słuchania to czas bycia razem");

- bezpieczny, bezpiecznie, bezpieczeństwo (np.: „Dziecko, (...), aby mogło się uczyć nowych rzeczy, potrzebuje czuć się bezpiecznie”; „Dzieci wysoko wrażliwe potrzebują bezpiecznych relacji w domu”; „(...) poczucie bezpieczeństwa oparte na wierze w możliwość pokonywania trudności”; „Kiedy dzieci widzą miłość, szacunek i otwartą komunikację pomiędzy parą obecnych rodziców, czują się bezpiecznie");

- bliskość, blisko (np.: „Dzieci regulują się przez ciało, czyli bliskość, ruch, swobodną zabawę”; „(...) pozwól mu być blisko Ciebie”; „Przeżywana wspólnie cisza daje nam poczucie bliskości drugiej osoby”; „dzieci potrzebują być blisko nas fizycznie i emocjonalnie");

- miłość (np.: „Będąc obecnym w ich (...) pozwalamy dzieciom wzrastać w bezwarunkowej, będącej tarczą ochronną na całe życie”; „Kiedy dzieci widzą miłość, szacunek i otwartą komunikację pomiędzy parą obecnych rodziców, czują się bezpiecznie").

\section{Wyniki i wnioski}

Z przeprowadzonych analiz wnika, że internetowe porady psychologiczne dla rodziców wyróżniają się przejrzystą, spójną strukturą, a ich kształt językowo-stylistyczny jest typowy dla stylu popularnonaukowego. Charakterystyczny dla tego rodzaju tekstów jest funkcjonalny zakres podawanych informacji, a także ich związek z bieżącymi wydarzeniami. Skutecznemu przekazywaniu specjalistycznych treści sprzyja ponadto zmniejszenie dystansu między nadawcą a odbiorcą oraz współwystępowanie elementów graficznych, które stanowią integralną część porad internetowych. Rozszerzenie zakresu pomocy dla rodziców w postaci profesjonalnych porad umieszczanych na ogólnodostępnym portalu edukacyjnym stanowi jeden ze sposobów ich wsparcia, służy również podnoszeniu kompetencji rodzicielskich, które można trenować i doskonalić (Jackiewicz i Białecka-Pikul, 2019, s. 20). 


\section{BIBLIOGRAFIA}

Bortliczek, M. (2017). Język w modelowaniu relacji dziecko - dorosły w tekstach popularnonaukowych dla najmłodszych. Poznańskie Studia Polonistyczne. Seria Językoznawcza, 24(44), 11-29.

Dakowicz, L., Halicka, M. i Skreczko, A. (2015). Kompetencje wychowawcze białostockich rodziców. Studia nad Rodziną, 2(37), 165-182.

Ficek, E. (2013a). Poradnik. Model gatunkowy i jego tekstowe wizualizacje. Wydawnictwo Uniwersytetu Śląskiego.

Ficek, E. (2013b). Rada a/i porada w przestrzeni komunikacyjnej. W: B. Mitrenga (red.), Słowo znaczenie - relacja w języku i w tekście (s. 143-159). Wydawnictwo Uniwersytetu Śląskiego.

Florczewska, K. (2002). Typy definicji w tekstach popularnonaukowych adresowanych do młodego odbiorcy. W: J. Miodek i M. Zaśko-Zielińska (red.), O trudnym łatwo. Materiały sesji poświęconej popularyzacji nauki (s. 186-194). Wydawnictwo Uniwersytetu Wrocławskiego.

Gajda, S. (1987). Społeczne determinacje nazw własnych tekstów (tytułów). Socjolingwistyka, 6, 79-89.

Handke, K. (2008). Socjologia języka. Wydawnictwo Naukowe PWN.

Heitzman, J. (2020). Wpływ pandemii COVID-19 na zdrowie psychiczne. Psychiatria Polska, 54(2), 187-198.

Jackiewicz, M. i Białecka-Pikul M. (2019). Kompetencja rodzicielska. Użyteczny konstrukt w badaniach nad rolą rodzicielskich oddziaływań w rozwoju dziecka. Psychologia Rozwojowa, 24(1), 9-28.

Jasińska, M. (2021, 3 lutego). Wysoko wrażliwe dziecko - kim jest? Librus Rodzina. https://portal. librus.pl/rodzina/artykuly/wysoko-wrazliwe-dziecko-kim-jest-czesc-1

Loewe, I. (2007). Gatunki tekstowe w komunikacji medialnej. Wydawnictwo Uniwersytetu Śląskiego.

Maćkiewicz, J. (2017). Badanie mediów multimodalnych - multimodalne badanie mediów. Studia Medioznawcze. Media Studies, 2(69), 33-42.

Makarewicz, R. (2017). Rozmowa w przestrzeni szkoły. Systemowo-funkcjonalna analiza poszerzonego dyskursu szkolnego. Wydawnictwo Uniwersytetu Warmińsko-Mazurskiego.

Nowak-Dziemianowicz, M. (2013). Narracyjne możliwości pedagogiki a kryzys kultury i wychowania. Forum Oświatowe, 3(50), 35-60.

Pikuła, N., Grewiński, M., Zdebska, E., Glac W. (red.), (2020). Wybrane krajowe i międzynarodowe aspekty polityki społecznej w czasie pandemii koronawirusa. Wydawnictwo Scriptum.

Pikuła, N., Jagielska, K. i Łukasik J.M. (red.). (2020). Wyzwania dla edukacji w sytuacji pandemii COVID-19. Wydawnictwo Scriptum.

Portal Librus, https://portal.librus.pl (dostęp: 21.02. 2021).

Portal Librus Rodzina, https://portal.librus.pl/rodzina (dostęp: 21.02.2021).

Puzynina, J. (1991). Jak pracować nad językiem wartości. W: J. Puzynina i J. Bartmiński (red.), Język a kultura (t. 2, s. 129-137). Wydawnictwo Wiedza o Kulturze.

Puzynina, J. (1992). Język wartości. Wydawnictwo Naukowe PWN.

Rawicka, I. (2020). Kryzys wychowania w wartościach i jego konsekwencje - analiza zjawiska na przełomie XX i XXI wieku. Studia Koszalińsko-Kołobrzeskie, 27, 405-420.

Seniów, A. (2017), Słownictwo psychologiczne we współczesnej polszczyźnie ogólnej. Wydawnictwo Naukowe Uniwersytetu Szczecińskiego.

Szylko-Kwas, J. (2017). Fotografia prasowa a podpis - ujęcie typologiczne. Studia Medioznawcze, $4(71), 137-150$.

Ślawska, M. (2008). Tytuł - najmniejszy tekst prasowy. Rocznik Prasoznawczy, 2, 117-126.

Tomasik, P. (1998). Pedagogika wobec kryzysu wychowania. Warszawskie Studia Teologiczne, 11, 287-318. 


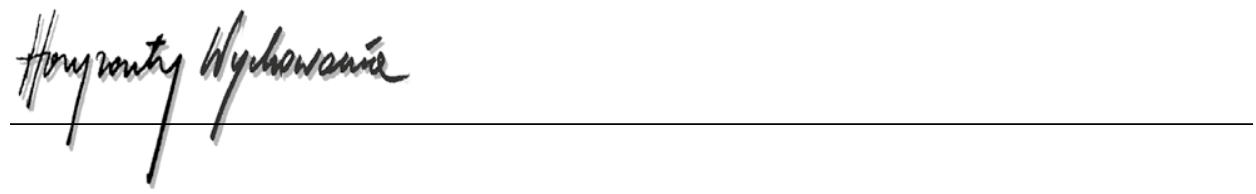

Wójcicka, M. (2006). Tytuł a stylowo-gatunkowe zróżnicowanie tekstu. Annales Universitatis Mariae Curie-Skłodowska, 24, 113-146.

Żydek-Bednarczuk, U. (2005). Wprowadzenie do lingwistycznej analizy tekstu. Universitas.

\section{Copyright and License}

This article is published under the terms of the Creative Commons Attribution - NoDerivs (CC BY- ND 4.0) License http://creativecommons.org/licenses/by-nd/4.0/ 